\title{
THE CANDIDATE POOL
}

\section{A treatment for the future.}

\section{BY BRIAN HURREL \& JEFF SAMSON}

CC

K people, let's make this quick," Frank Poole snapped. He gazed around the table at the assortment of harried-looking men and women. "Jenkinson will be arriving in 20 minutes, and I want this wrapped up before he does." He brushed a hand through a thick shock of silver hair, shot his cuffs and jabbed a finger at the man to his right. "Holderman, what have you got?"

The young man cleared his throat with preppy politeness and held up a stack of notes. "Think of it as Primary Colors meets Sid and Nancy. Sex, drugs, love children, murder-suicide. Absolutely scandalous."

Poole shook his head. "No good." He continued clockwise around the table, snapped his fingers at a lithe, hatchet-faced blonde. "Paladino. Talk to me."

"Soylent Green meets The Sum of All Fears," she said. "Twenty per cent unemployment, food riots, an increasingly anarchic southern border, and a nuclear terror strike on Washington for good measure."

"Absolutely not," said Poole. "Who's next? Stormont."

"Massive environmental chaos caused by deregulation and corruption," said Stormont. "We're talking entire ecosystems destroyed. Total societal breakdown. Bandits, fortified towns, cannibals. Think The Day After Tomorrow meets The Road Warrior."

Poole leaned back in his chair, his stare fixed on the gaunt young man with hornrimmed glasses and a five o'clock shadow at 7 a.m.. He swivelled, rapping his fingers on the table. "Hmm ... that's a tough one ... I mean, who doesn't love The Road Warrior?" Poole shot forward, bracing himself with his hands on the edge of the table. "No."

He pointed at the man directly across from him. "Bumstead. Wow me."

"Progressivism gone wild," said the smallish man sporting a third-degree tan and a shimmery suit he couldn't afford. "Ultra-nanny state with soaring deficits, unfunded liabilities and industry-crippling legislation. Individual liberty a distant memory - the Constitution and Bill of Rights dismantled and replaced with the Articles of Fairness and the ..." he paused, smirking, "Feel Good Doctrine."

Poole stared at the man. "Is that a joke?"

"I'm afraid not, sir,"

$\rightarrow$ NATURE.COM

Follow Futures:

3 @NatureFutures

f go.nature.com/mtoodm he continued. "Think Atlas Shrugged meets 1984, only decidedly less optimistic."

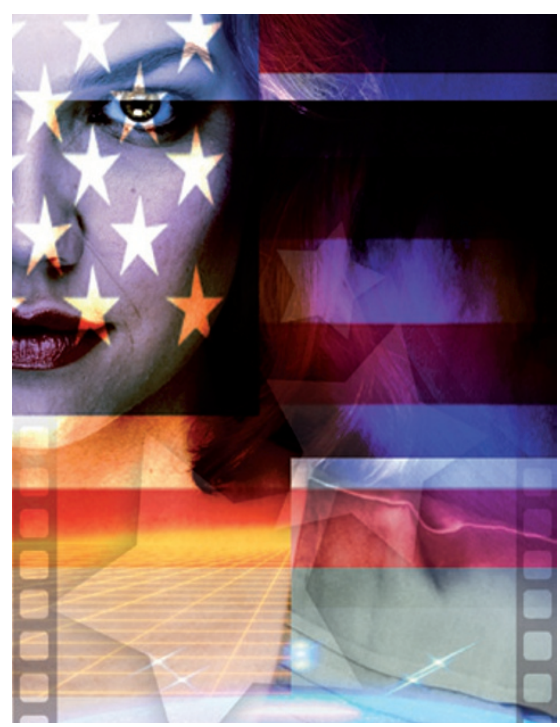

Poole slammed a fist on the table. "Enough with the dystopias! This can't be all you've got for me!" He glowered at the old but wiry-looking man at Bumstead's left. "Nalesnik, give me something ... anything!"

Nalesnik threw his bony hands up dramatically. "Imagine The Undiscovered Country - but not in space - and The Parallax View, combined. An assassination during an inaugural speech, a military coup, a -"

"Christ!" Poole exploded. "Didn't I just say no more dystopias? We're running out of time, people."

He gestured to a 30-something who would have been quite attractive without her oversized sweater, shapeless hair helmet and thick-rimmed reading glasses. "Wellington, I'm going to assume you don't have a top hat full of rabbits on your person."

The woman clasped her hands, straightened her back and sighed loudly. Her voice was halting. "It's A Wonderful Life meets The American President ... with shades of Leave it to Beaver and Pleasantville."

Poole's eyebrows shot towards his hairline. "Go on," he said, his voice uncharacteristically bright.

"A complete societal shift. Crime, employment, divorce, patriotism, trust in government ... even table manners - all at levels not seen since the 1950s. In short, a resurgent America. A world leader again."

"I'm liking it," Poole said, rubbing his hands together. "Who's your lead?"

"Barbara Gundermunsen."

"Gundermunsen? From Fargo?” Poole shook his head. "I don't buy it. Her record and disposition aside, her name alone is more than most people can swallow. It's four syllables, for chrissake."

"Eisenhower has four syllables," interjected Bumstead.

Poole glared at the man in the sleek suit. "Why do you think everyone called him Ike?" he snapped. "And Gundermunsen doesn't shorten well."

"No," said Wellington, her hair flopping from side to side as she shook her head. "But that's irrelevant. In time they'll call her the Iron Maiden." She started to push her papers across the table, but paused, her face seeming to flush and harden. She breathed in deeply, exhaled, then slid her treatment towards Poole's twitching fingers. "It's all there."

The woman shifted uncomfortably in her seat as Poole skimmed the pages with a widening smile. She cleared her throat in exaggerated fashion. "Not to rain on the inaugural parade, but Chairman Jenkinson would be furious if he knew what was going on here. He's as straight as they come."

"Then it's a good thing he never will, isn't it?" Poole said without looking up.

"But sir," she said, "this isn't just highly unethical. It's illegal. If the Fair Election Commission or the House Committee on Temporal Integ - "

"My dear," said Poole, locking eyes with her, "if you think for a minute that the other parties aren't testing the waters of every possible time stream, then you're too naive to be in this business."

"I just don't care for it, sir," she said.

"Sometimes you have to do the wrong thing to do the right thing. Capiche?"

"Yes sir."

"Right. Now that we've taken care of our moral qualms, let's tell Senator Gundermunsen that she is now the official Technocratic candidate for the 2036 presidential race."

The people around the table rose, gathered up their documents and scattered. Poole leaned back in his chair and flipped to the next page of the treatment. "Wellington," he shouted, stopping her hurried exit.

"Yes?" she asked, turning to face him.

"You're sure about this? Meek and mild Barbara Gundermunsen?" he asked, dubiously.

"The Iron Maiden ... sir," she intoned.

Poole looked back at the treatment and smiled broadly. "I think we have a winner."

Brian Hurrel and Jeff Samson live in New Jersey with their families. They thank their wives for tolerating their collaborations. 